\title{
A CASE OF CULTURAL MISUNDERSTANDING: French Anthropology in a Comparative Perspective
}

\section{VINCENT DEBAENE \\ Columbia University}

In 2010, the University of Wisconsin Press published what was presented as the "twelfth and final" volume of the influential "History of Anthropology" series: the autobiography of its founder, George Stocking. Through this curious gesture, both reflexive and conclusive, a moment of anthropology (and of historiography) was officially declared closed. It was as if one could claim that the history of the discipline had now been "covered," at least for a while, following the appearance of several volumes on the British, American, and German anthropological traditions. It is obvious, however, that many national traditions are missing from this picture. Among those absences, one seems particularly striking: that of French anthropology. This is not to say that French anthropology deserves more respect or attention than, say, Japanese or Russian anthropology. But given the rich and more than century-long history of dialogue and exchange between English- and French-speaking social scientists, it is surprising that no extensive study was ever devoted, as such, to a tradition that produced thinkers as influential as Emile Durkheim, Marcel Mauss, Claude Lévi-Strauss, or Pierre Bourdieu.

In 2011, the University of California Press published a special 25th anniversary edition of Writing Culture, with a new foreword highlighting the book's international influence. This collection has been critical to many developments in the field of anthropology and beyond and has been translated into Mandarin, Greek, Italian, Japanese, and Spanish_ - but never into French, a fact all the more striking 
when one considers the strong presence of French authors and texts in this seminal book and more generally in 1980s and 1990s reflections on the poetics of anthropology.

These publication realities seem to indicate a sort of mutual deafness, or at least the cultural specificity of French anthropology, as if it could not quite be converted into the frames of reference of an increasingly globalized English-speaking anthropology or integrated into the accepted narratives of the discipline. Although Mauss and Lévi-Strauss remain both part and parcel of the anthropological canon and required reading for any aspiring anthropologist, there seemed to be a combined resistance both of French anthropology to a certain type of epistemological consideration (the 1970s and 1980s "literary turn" of the discipline and its political implications) and to French anthropology (which could not find its place in the canonical accounts of the evolution of the discipline as they were established in the wake of this literary turn).

This article attempts to shed light on this specificity through a study of French ethnographic writing practices and their evolution over the course of the 20th century. My general hypothesis is that this resistance stems from the particular bent of the French anthropological discipline toward literature and from the fact that French anthropology combines two seemingly antagonistic tendencies. On the one hand, the French tradition privileges a strong literary dimension, one which is visible in the proximity between anthropological circles and avant-garde artistic ones, as well as in the way French anthropologists portray themselves as heirs of Montaigne, Rousseau, or even Pascal. At the same time, there is an equally strong anti-literary stance, the consequence of a deep and general distrust of rhetoric, which can be found both in the Durkheimian legacy (anthropology and sociology are explanatory sciences devoted to the description and analysis of social and mental facts) and in the institutional construction of anthropology as a museum-based discipline, first around the Musée d'ethnographie du Trocadéro, then around the Musée de l'homme.

This dual identity appears most often through a phenomenon striking in its recurrence: French ethnographers, in addition to their scholarly work, often write a "second book," a more literary account of their experience in the field. The most famous cases are those of Michel Leiris, author of La Langue secrète des Dogons de Sanga (1938, published in 1948) and of L'Afrique fantôme (1934), and of Claude Lévi-Strauss, who wrote both La Vie familiale et sociale des Indiens nambikwara (1948) and Tristes tropiques (1955). But these pairs of books are just two examples among many others, and in fact, Tristes tropiques is a rather belated illustration of a tradition 
of "double writing" which dates back to the 1930s, a tradition that it both prolongs and subverts at the same time.

In what follows I first characterize this phenomenon of the "double book" in more general terms before turning to Alfred Métraux's fieldwork on Easter Island in 1934 35, and then consider the case of Tristes tropiques. By analyzing the specific and ambivalent relationship of French anthropology to literature, I hope to shed light on some of the recent difficulties in cultural and intellectual translation between French social sciences and American anthropology.

\section{THE ETHNOGRAPHER'S DOUBLE BOOK}

In the 1980 s and $1990 \mathrm{~s}$, it was common to recount the destiny of anthropology as the progressive resolution of the contradictions that weighed on the first decades of the discipline. In an oft-quoted 1991 article, Barbara Tedlock explains that the "oxymoron 'participant observation"” had embodied a true double bind, forcing ethnographers "either to suppress the actual events that [had taken] place during the research" or to "publish the fieldwork experience as a novel," as famously illustrated by the example of Laura Bohannan's Return to Laughter, published under the pseudonym Elenore Smith Bowen (Tedlock 1991:72). The too-few tales of fieldwork produced by professional ethnographers in the $1930 \mathrm{~s}$ and 1940s were symptoms of this contradiction, which felt more and more unbearable. As it became more generally accepted that "ethnography is both a product and a process" and that anthropology is a coproduced knowledge, personal aspects of the research, contingent events, expression of affects, and participatory details were gradually allowed into academic work, rendering "supplementary" tales of fieldwork unnecessary. According to this reading, one would have gone from a complex and painful alternation between two sets of methodological requirements (participation/observation) and between two different writing practices (personal in the field notes/impersonal in the scholarly work) to a more reconciled form of ethnography, one that could focus on dialogue and encounter rather than on description, one that could be more happily reflexive and polyphonic, and to an ethnography that could acknowledge without guilt the fundamental ties between anthropology and literary writing practices (see also Bruner 1993).

Both Barbara Tedlock in her 1991 article and James Clifford in his introduction to Writing Culture mention Tristes tropiques and L'Afrique fantôme as early symptoms of the double bind between subjective participation and objective observation, foreshadowing the calling into question of anthropological representational conventions in the 1970s and 1980s. Leiris's diary and Lévi-Strauss's memoir are some of the 
"rare" "first-person, experiential writing by ethnographers dealing with actual people and events ... during the 1930s, 1940s and 1950s," writes Tedlock (1991:74), and Clifford considers them both, along with Laura Bohannan's Return to Laughter, as "earl[y] disturbances" of "the prevailing subjective/objective balance" that were "kept marginal” (Clifford 1986:13). However, neither L'Afrique fantôme nor Tristes tropiques is isolated; in fact, the opposite is true. They are not marginal outbursts of subjectivity in a world of objectivistic anthropology. For the first generation of French ethnographers - to which both Leiris and Lévi-Strauss belong ${ }^{1}$ — such a distribution of ethnographic experience into two books is strikingly widespread: most wrote a "second book," a literary account of their experience in the field, in addition to their scholarly work. Of course, they published their results (most of the time, their $\mathrm{PhD}$ thesis) in specialized series, many of which had just been created at the Institut d'ethnologie or at the Musée de l'homme. But also, in addition to this very specialized monograph on a certain rite or a certain linguistic family, most of them wrote a literary "supplement" published by a more generalist press such as Gallimard, Grasset, or Plon.

After the publication of Silhouettes et graffiti abyssins (1933) and Jeux et divertissements abysins (1935), two collections of documents gathered during his first fieldwork in northern Ethiopia, Marcel Griaule was awarded the Prix Gringoire, a literary prize, in 1935 for Les Flambeurs d'hommes (1934), an odd book narrating his experience in the field in the third person. In the same way, while Jacques Soustelle was preparing for the defense of his doctoral thesis on both the material culture of the Lacandon Indians and on the Otomi-Pame linguistic family, he was writing Mexique, terre indienne (1936), published by Grasset, and presented by Paul Rivet in his preface as an alliance between "shrewdness and generosity" (Rivet 1995:7-8). Between 1932 and 1939, Maurice Leenhardt gave three heavy volumes to the series "Travaux et mémoires de l'Institut d'ethnologie" on the ethnography and language of New Caledonia, but he also received the literary Prix La Pérouse in 1938 for Gens de la Grande Terre (1937), a much more accessible book published by Gallimard in the series "L'Espèce humaine." And one could find additional evidence of the same pattern in the work of Alfred Métraux, Jehan Vellard, and Paul-Emile Victor, among others. These pairs of books raise an obvious question: Why do ethnographers feel the need to add a "literary" supplement to the scientific text? ${ }^{2}$

In attempting to answer this question, I would first note that those pairs do not line up with each other. The relationship between Tristes tropiques and Lévi-Strauss's doctoral thesis on the Nambikwara Indians is not similar to the relationship between L'Afrique fantôme and Leiris's work on possession, which in turn is not similar to the 
relationship between Malinowski's diary and Argonauts of the Western Pacific. And this is in itself a lesson: multiplicity of writing practices is not necessarily the symptom of one single recurring epistemological contradiction. It cannot be reduced to a mere tension between a repressed subjectivity and a quest for objectivity or to any other dichotomy such as explanatory/interpretive or narrative/descriptive; the meaning of those dualities is relative, contingent on local conceptions and practices. Furthermore, contrary to the American and British traditions where the second book used to be "considered embarrassingly unprofessional" (Tedlock 1991:71) for example, Malinowski's diary, kept hidden for 50 years, or Laura Bohannan's pseudonymous tale Return to Laughter - the literary supplement in the French tradition is not kept secret. It is not even considered unprofessional or potentially controversial. Though Griaule, the head of the Dakar-Djibouti expedition, broke with Leiris after the publication of L'Afrique fantôme because he rightly feared that Leiris's diary would taint the reputation of the new anthropological discipline with its disclosure of the mission's unethical museum-collecting procedures, other ethnographers such as Alfred Métraux or André Schaeffner praised the book for its "authenticity" (see Schaeffner quoted in Leiris 1996:359). And if Paul Rivet, the founder of the Musée de l'homme, was wary that Lévi-Strauss was revealing too overtly his professional doubts in Tristes tropiques (see Lévi-Strauss 1991:87), his was a rather marginal position: reception among anthropologists as well as among the general public was widely positive (see Debaene 2008). In most cases, the second book is made widely available and very well received, as evidenced by the award of literary prizes to Griaule and Leenhardt, or by Rivet's glowing prefaces for Vellard's La Civilisation du miel and Soustelle's Mexique, terre indienne. Obviously, this eminent founding figure of French anthropology did not fear that the discipline would be unsettled by these personal accounts.

Last, the acceptance of the literary supplement is all the more striking in that French ethnographers of the period state strongly that they are not literary writers or "littérateurs." To them, the study of man has entered the scientific age; the new discipline has cut the ties that used to connect anthropology to the tradition of travel writing and literary exoticism. Again, this is specifically French. If Malinowski occasionally compared his work to that of a physician, he also insisted on the necessity of "local colour" and on "the paramount importance of vividness and colour in descriptions of native life" (quoted in Manganaro 2002:59). In the preface to Argonauts of the Western Pacific, Sir James Frazer famously praises Malinowski's work for "see[ing] man, so to say, in the round and not in the flat," comparing it to the "presentation of human nature in the great[est] artists, such as Cervantes 
and Shakespeare" (Frazer 1922:ix). Beginning in the 1920s, it became fashionable among the students of Boas to compare anthropology to an artistic endeavor (see Handler 1983, 1990); and Sapir, comparing the anthropological collection American Indian Life to "the exotic element in Lord Jim and Heart of Darkness," could even dream of "fusing" "the conscious knowledge of the ethnologist . . . with the intuition of the artist" (Sapir 1922:570). French anthropologists strongly rejected such analogies: "It would be wiser," Griaule states on his return from Gojjam, Ethiopia, "to try to understand the soul of this great people in some way other than through shallow investigations by littérateurs and dilettantes. It is more than time to seriously consider the social facts in which this soul reveals itself, and to grant them the honor of being studied as a chemical reaction or as a physical problem of the resistance of materials" (Griaule 1930). When prefacing Griaule's work on “Abyssinian games," Marcel Mauss makes clear that "there was no aesthetic investment in this work: this publication is strictly scientific, without any adornment” (Mauss 1933:5).

Scientific ethnography is to be grounded on well-established facts and does not indulge itself in "impressionism" or "local color" for audience appeal. The key notion in this turn toward scientific anthropology is the document. "We are not writing accounts; we are producing documents" seems to be the motto of this generation. This shift begins with the reorganization of the Musée d'ethnographie du Trocadéro according to scientific criteria in 1929-30, and concludes with the building being finally demolished to make room for the new Musée de l'homme in 1938. A case study will help clarify the paradoxical combination between this strong and explicit refusal of "literature" and the almost systematic publication of a literary supplement.

\section{A CASE STUDY: Alfred Métraux's L'Île de Pâques}

Alfred Métraux was one of the first students to receive his "certificat d'ethnologie" at the Institut d'ethnologie, in 1927. He undertook several fieldwork expeditions, mainly in Argentina and Peru, and then was sent by Rivet to Easter Island as the French head of the Franco-Belgian "Mission Île de Pâques," spending six months there in 1935 before spending eighteen months in Honolulu as a research fellow at the Bishop Museum. The main task Métraux had set himself was to retrace the origin of Easter Island's inhabitants and to dissipate all eccentric hypotheses regarding the island, its peopling, its history, its material and immaterial culture. This work culminated in a 430-page monograph published by the Bishop Museum, entitled Ethnology of Easter Island (which is still considered a reference now 
although some of its content appears obsolete). The aim of the book is to "sho[w] that Easter Island is a local Polynesian culture which developed from an archaic and undifferentiated Polynesian civilization" and that it "represent[s] a specialization and an achievement which local conditions explain sufficiently without the interpolation of a sunken continent or Melanesian invasion” (Métraux 1940:420). While he was working on this very scholarly monograph, however, Métraux was also writing L'Île de Pâques, published by Gallimard in its series "L'Espèce humaine" in 1941. This latter work was described 15 years later by Georges Bataille, Alfred Métraux's friend and former classmate, as "one of the masterpieces of current French literature" that "surpasses by far the mass of novels that the public receives as literature" (Bataille 1956:100).

In the preface as well as in a few articles and in his correspondence, Métraux presents L'Ille de Pâques as a popular version of the scholarly monograph. However, a comparison between Ethnology of Easter Island and L'Île de Pâques quickly reveals that this is not the case; L'ille de Pâques is not a translation of a technical book for a wider audience. To understand the nature of the relationship between the two books, we need to turn to those passages where Métraux develops his main hypothesis: "Understanding a historical event [the migration from Polynesia]," Métraux explains, "does not only require that one know the way it happened or the causes it originated from. One needs in addition to recreate its psychological atmosphere" (Métraux 1941:31). Later in the book, as he is trying to "reconstitute the life cycle of a Pascuan from birth to tomb," Métraux says: "The change has been so deep that it seems almost impossible to reconstitute the social and moral atmosphere in which a native used to live eighty years ago" (Métraux 1941:88).

These two quotes shed light on the very aim of L'Ille de Pâques, namely to re-create and convey the social atmosphere of the island in the 19th century (before it was almost entirely depopulated by Peruvian slave raiders in the 1860s). This notion of social atmosphere is pervasive in French ethnographic texts of the 1930s. At the very end of Mauss's The Gift, for instance, the gift itself is described as an "atmosphere" "where obligation and liberty intermingle" (Mauss 2002:83). Several times in his Manual of Ethnography, Mauss insists on the need "to define the moral tone of a society, making an effort to remain within the ethos [the original reads atmosphere] of the society: it is good to practice the vendetta; it is good to be able to offer a human head to your fiancée" (Mauss 1990:157). Griaule's Méthode de l'ethnographie denounces the insufficiencies of museum collection: "This manner of gathering concrete human facts [museum collection] now appears obsolete and 
insufficient. . . I It would be a petty victory to gather those silent testimonies without being able to recreate, through intensive documentation, the atmosphere of the society that produced them" (Griaule 1957:29).

The notion of atmosphere and its equivalents, such as the phrases "social climate," “moral climate," and “moral tonality," go back to Marcel Mauss's social theory and his teaching at the Institut d'ethnologie de Paris. These phrases all stress that beyond material productions, beyond even institutions or juridical rules, what differentiates societies are certain "ways of thinking," certain "ways of feeling" ("les façons de penser, les façons de sentir"), a certain "atmosphere.” The social fact — which, since Durkheim, has been set as the object of anthropological knowledge - does not only appear through tools or techniques or masks; nor is it even reducible to social organization. The social fact is first and foremost a moral fact, a mental fact. As Mauss would have it: "We shall no longer be studying things that can be held in the hand or that are visible, but above all states of mind [the original reads états de conscience, states of consciousness]" (Mauss 1990:83). That is also why ethnographers need to go into the field: not primarily to participate (the idea of "participation" is quite foreign to the French tradition) and not only to collect first-hand data, but to experience the inner dispositions of the members of a given society as they are socially constructed, to be "impregnated" by the social atmosphere and to breathe the "air" of social life in the community they have chosen to study.

This redefinition of the social fact, however, is not compatible with a positivistic definition of anthropology as a museum-based discipline. How can one give a correct image of a "social climate" with monographic collections of texts and documents, with objects cut off from their original context, with traditional tools and ritual masks exhibited behind windowpanes? Hence a dual discourse emerges among ethnographers. On the one hand, they are eager to show that their discipline has reached the scientific stage; that it now has its Institute and its Museum; that a crew of trained professionals is now traveling around the world, methodically collecting data, "before it is too late." On the other hand, they keep complaining that the document is not enough, that the pieces that are exhibited in the Musée de l'homme are unable to restitute the "moral climate," the "moral atmosphere," the "tonality of social life" in the small communities they have studied.

In many cases (not in all), this is the reason for the ethnographer's second book: it stems from the attempt to reconcile the need for objective facts with the need for a more suggestive kind of representation - for évocation. There is a double bind at the core of ethnographic practice in France in the 1930s, evidenced even in ethnographic 
handbooks of the time. The first two pages of Mauss's Manual of Ethnography describe ethnography as a "science of recording" (science d'enregistrement); the ethnographer's main goal is to collect and bring together well-established documents and to objectively describe the society he studies. However, the very last sentence of this introduction reads: "Sociology and descriptive ethnology require one to be at once an archivist, a historian, a statistician . . . as well as a novelist, able to evoke the life of a whole society" (Mauss 1990:7). Even Griaule, the strongest advocate of scientific ethnography in the 1930s and beyond, sometimes gives way to doubt. In the part of his Méthode de l'ethnographie devoted to "recording," he states, "artistic effects should be considered with the utmost distrust" (Griaule 1957:83). But at the end of the last chapter, devoted to the "exposition of the results," he seems to realize that such a dismissal of stylistic effects might not be quite applicable, or even desirable: "It is . . necessary to present facts in detail to the reader . . . , reducing the author's intervention to a minimum. Conversely, if one considers the atmosphere in which the facts took place, the author is allowed to include impressions, subjective incidents that will be all the more useful to the description. ... One has then to satisfy two contradictory necessities. The author needs to disappear when he is exposing the course of a rite, and on the other hand, he needs to draw from all the resources of his personality to render the atmosphere of the rite. In the former case, he will use a cold, even flat, style; he will sacrifice all literary effect in favor of precision. . . . In the latter case, he shall be a good littérateur" (Griaule 1957:103-104). The same ethnographer who, in 1930, was dismissive of "shallow investigations by littérateurs and dilettantes" is finally admitting that being a "good littérateur" might help not only in conveying anthropological knowledge, but also in being more exact and accurate.

Of all the ethnographers of the time, Métraux is probably the one who thinks most thoroughly about what the reconstitution of an atmosphere would require and imply. In a letter to Leiris, sent from Honolulu in May 1936 as he is working on L'Île de Pâques, he writes: "the ethnographer . . should study his tribe as a novelist would do and bring it to life using perspectives and devices borrowed from the art of the novel. ... To show the mechanism at work; not to take it apart and order the pieces according to totally random and empirical rules. To see them dismantled, see Mauss's manual. No, what I want is to keep all these combinations for myself, while rendering for others the feeling of life that the contact with other men should create" (quoted in Poitry 1995-1996). And indeed, in L'Île de Pâques, Métraux uses all the narrative and rhetorical tools one can think of: he plays on verb tenses; he engages in ekphrasis (what he himself calls "imaginary 
paintings"); he quotes from native myths and legends; he reconstitutes the "life cycle" of the ancient inhabitants of Easter island using free indirect speech; and of course, he devotes several pages to the erection of the famous statues: "One should not however project in the middle of the Pacific Ocean the familiar depiction of the building of Egyptian pyramids. . . . It is the joyful agitation of feasts that we need to evoke when we think of this effort" (Métraux 1941:152-153). Later on, he describes the surroundings in which he records the legends told by his main informer in the following terms: "Let the reader imagine great fields of stone, a coal-like bank, verdant hills in the far distance, and the sea, on which bronze plates seem to float, the sea, that old friend of the Polynesians, whose waves and winds brought the first men to the very bank where I was listening to their tales" (Métraux 1941:180). Just as striking as the "Chateaubriand-like" prose of L'Ile de Pâques are the recurring injunctions: "One should picture"; "One should not imagine . . . but rather think of . . "; "Might the reader imagine . . "; and so on. They all insist on the extremely ambitious attempt to reconstitute and convey a "moral atmosphere."

\section{ETHNOGRAPHY, RHETORIC, AND THE DOCUMENT}

In Métraux's L'Île de Pâques (Soustelle's Mexique, terre indienne and Leenhardt's Gens de la Grande Terre would be equally telling examples), one can observe the resurgence of a rhetorical conception of literature: literature appears as the technical art that renders moral and immaterial realities vivid and that, ideally, enables the reader to subjectively experience them. If the object of anthropology is to document "ways of thinking and ways of feeling," then the goal of the literary book is, more often than not, to make the reader feel those ways of feeling. Thus ethnographic handbooks of the 1930s and 1940s returned to rhetorical categories and challenges that had been discarded both by the development of modern literature since the mid-19th century and by the development of science in a "positivistic" epistemological context.

The 1850s can indeed be considered a turning point in the history of French literature: Flaubert's and Baudelaire's literary innovations severed the ties between literature and the rhetorical tradition. From then on, literature is defined as pure work on language, without any communicative or representational function. Moreover, as of the 19th century, in the field of science-from natural history to sociology - rhetoric is widely regarded as a mere repertory of figures, a suspect technique that appeals to the reader with no concern for the truth, "un art de parler bien sans penser" (an art of speaking well without thinking) (Lanson 1964:58). Rhetoric and rhetorical issues are banned on both sides, so to speak, excluded from both the course of literature and the investigations of science. 
But ethnographic texts in the 1930s resuscitated some of these earlier tasks associated with literature: how does one re-create and communicate a "state of consciousness"? How can one elicit a similar state of consciousness in the reader's mind? What stylistic devices are needed to convey a "moral climate"?

This resurfacing of an instrumental conception of literature in the 1930s mitigates the idea of a proximity between French anthropology and the French literary avant-garde. Several decisive studies have indeed shown the connections between early French ethnography and French post-surrealist writers, which encounter each other around the idea of the document (see Clifford 1981; Jamin 1986; Hollier 1992). As James Clifford explains in his famous article on "ethnographic surrealism," ethnographers and surrealists were linked by a common refusal of aesthetic hierarchy: students of Mauss and followers of Breton shared the idea that beauty and artistic value are not relevant criteria for approaching cultural productions. Similarly, in his seminal work on the fascinating journal Documents (created and led by Georges Bataille), Denis Hollier (1992) convincingly accounts for the wide diversity of authors in the table of contents of the journal (scholars, anthropologists, archaeologists as well as avant-garde artists and poets) by drawing attention to their shared concern for the "techniques de corps" and the privilege they assigned to the use-value of the object rather than to its exhibition-value (to borrow from Walter Benjamin's categories). All this accounts for an encounter between the avant-garde and the new "science of man" ("science de l'homme") on the common ground of an anti-art stance and a suspicious attitude toward rhetoric, aestheticism, and the institution of literature.

For many ethnographers, however, a much more conventional conception of literature prevailed. Whereas the avant-garde looks to ethnography for its documents and for its alleged ability to shake off representative conventions, most ethnographers look to literature for its alleged ability to evoke moral realities. But surrealists and avant-garde poets do not care about the talent or the "literary skills" of the ethnographers, consecrated though they may be by literary prizes. Conversely, Griaule claims that the ethnographer has to be a "bon litterateur," and Mauss would like the ethnographer to be a novelist. But to surrealists, "littérateur" is an insult, and they hate the novel, particularly the realistic novel that "flatters the basest tastes of its readers" and "arises from mediocrity, hatred and dull conceit" (Breton 1974:6).

This non-representational conception of literature, with its fierce rejection of rhetoric, is specifically French, and extends far beyond the 1930s. It gave birth to forms of exchange and circulation between the anthropological discipline and 
the literary sphere, which are quite different from the exchanges and connections between American anthropology and literary modernism in the 1920s. Granted, there are similarities between Leiris's or Griaule's discomfort with the "inhuman" science of anthropology and the complaints by Boas's students who, like Sapir and Radin first, then Benedict and Mead, rejected their professor's empiricism and came to explore literary conventions for conveying the "pattern" of the culture or its ethos (Handler 1983:212-218). And the reflections on novelistic techniques by Alfred Métraux (undoubtedly the French ethnographer most familiar with American anthropology) recall those by Sapir on perspective and "subjective realism" (Sapir 1917; see Handler 1983). But those analogies must not cause us to overlook the decisive differences. French ethnographers never thought of abandoning monographic work in favor of another representative mode: there are indeed two books, one of them only being regarded as scholarly. The fusion that Sapir dreamed of between "the conscious knowledge of the ethnologist" and "the intuition of the artist" is never envisaged, not even by Métraux: it would have been experienced and perceived as a betrayal of the scientific project of the discipline (in the same way that a comparison between the anthropologist and Cervantes or Shakespeare would have done). Similarly, there is no divide, among Boasians, between a scholarly work and a literary account for a wider audience, and none of them wrote this kind of supplementary tale of fieldwork completing the scientific study.

Whereas exchanges between anthropology and literature in Great Britain and the United States are rooted in a common reflection on the notion of culture (Handler 1986; Hegeman 1999; Manganaro 2002), this same notion is strikingly absent from the French social sciences. Ethnographers trained by Mauss were not trying to grasp an ethos, they wanted to breathe an atmosphere: they were not deciphering patterns, they were seeking a radical mental transformation (see Métraux 1988). Although it was rarely explicit, the bodily experience of the ethnographer was seen as central since "the social" is by essence incarnated, "in body and in mind" (as 18th-century theories of climate would have it). This bodily experience became a precondition for the comprehension of the social fact as opposed to the understanding of culture, a concept that Mauss described as "even worse" than that of civilization, itself already "pretty bad" ["assez mauvais"] (Mauss 2004). The foreignness of French anthropology from an American perspective comes in part from this very simple fact: it is an intellectual tradition which never made culture a key concept and which, from Durkheim to Lévi-Strauss to Bourdieu, always refused to acknowledge what Bourdieu called "the old Diltheyan distinction" between explaining and understanding (Bourdieu 1993:1400; see also Dianteill 
2012). French anthropology's relationship to literature, when it is present, does not imply any hermeneutic stance and rarely involves a "cultural representation": it takes place either earlier in the construction of anthropological discourse - in the bodily experience of the ethnographer and its translation into words - or laterin the reflections on ways to use, display, and present the results of the work performed.

\section{TRISTES TROPIQUES, OR FROM THE SECOND BOOK TO THE FIRST}

Most second books written by French anthropologists in the 1930s try to compensate for the insufficiencies of a positivistic conception of anthropology without renouncing it. Métraux's L'Île de Pâques, Maurice Leenhardt's Gens de la Grande Terre, Marcel Griaule's Les Flambeurs d'hommes, or Jacques Soustelle's Mexique, terre indienne can be read as attempts to restitute an insistent but elusive "atmosphere" that even the best-established document or the most thorough monograph are unable to transmit, as (unsatisfying) ways to reconcile the need to restitute an immaterial and mental object with the call for an objective, document-based science.

I propose to read Claude Lévi-Strauss's 1955 Tristes tropiques in this light, as a book that both recounts this theoretical impasse, as experienced by the young LéviStrauss in the 1930s, and offers a way out of it. The beginning of Tristes tropiques offers a striking example of the persistence, or the revival, of such a rhetorical conception of literature. In the famous chapter, entitled "Sunset," Lévi-Strauss quotes a long description of a sunset he wrote on the deck of a ship as he was about to cross the Atlantic Ocean in February 1938. Later, this passage was considered an anticipation of the French nouveau roman's care for minute, endless descriptions, resonating with Lévi-Strauss's alleged formalism in anthropology. A careful look at the text, however, reveals the opposite. Instead of a literary experiment, this passage was initially conceived as a stylistic exercise, like those assigned to students of rhetoric in the 19th century: for instance, "You will compose a sunset in the manner of Chateaubriand." Lévi-Strauss justifies his attempt by the desire to "find a language in which to perpetuate those appearances, at once so unstable and so resistant to description": "if it were granted to me to be able to communicate to others the phases and sequences of a unique event which would never recur in the same terms, then - so it seemed to me-I should in one go have discovered the deepest secrets of my profession: however strange and particular the experiences to which anthropological research might expose me, there would be none whose 
meaning and importance I could not eventually make clear to everybody" (LéviStrauss 2012:62).

Lévi-Strauss later recounted that this piece, written in 1938, was initially intended as the first chapter of a "vaguely Conradian novel" that would have paralleled his then to-come monograph on the Nambikwara (Lévi-Strauss 1991:91; see Debaene 2008:1693). As such, it would have fit perfectly within the French tradition of the two books: successful fieldwork giving birth to both a scholarly study for professionals and a literary account rendering the more subjective aspects of the experience. Unfortunately, the fieldwork among the Nambikwara Indians did not meet the expectations of the young ethnographer once eager to "make clear to everybody" the "strange and particular experiences to which anthropological research might expose [him]" (Lévi-Strauss 2012:62). The young Lévi-Strauss discovered in his exploration of central Brazil that the major difficulty of the ethnographic encounter was not to render the "atmosphere" of the native society to (Western) readers; rather, it was to experience it in the first place. Trying to penetrate the cohesion of Nambikwara society in the fall of 1938, Lévi-Strauss cannot but note that his object is vanishing: "I had been looking for a society reduced to its simplest expression. That of the Nambikwara was so truly simple that all I could find in it was individual human beings" (317).

What is remarkable, however, is not that Tristes tropiques narrates the failure of this (heroic) model of fieldwork. In that, the book would simply have provided a slight variation on the two-books pattern, the disenchanted literary account replacing the usual more novel-like evocation of the society. Bitterness and tristesse would have replaced heroism and conquest but not radically changed the paradigm, since indeed there is no such thing as an entirely negative disenchantment: there is always a lesson to draw from disillusion. No, what is remarkable is that LéviStrauss does not satisfy himself with honestly confessing his failed experiences: he reinscribes them in a series of events that appear meaningless when taken alone, but are highly significant when aligned in series.

Going back to his youthful stylistic attempts, an ironic ethnographer would have mentioned them as (laughable) evidence of his own naïveté. But 17 years after "those feverish moments" spent "notebook in hand," attempting to jot down "the evanescent and ever-renewed forms" of the sunset, Lévi-Strauss (2012:62) does not poke fun at the young ethnographer he once was. He extensively quotes his notes - as a naive attempt, yes, but also as a felicitous moment of successfully reconciling sensory experience with intelligibility. This latter meaning, however, does not immediately appear as such: in accordance with a pattern that surfaces 
again and again in Lévi-Strauss's later work, it is fully assumed only afterward, in the process of ordering past experience. The meaning of the sunset can only be grasped because it has been compared and aligned with other "epiphanic" episodes: the association between the word Brazil and the image of "bizarrely designed kiosks and pavilions" combined with the "smell of burning perfumes" (47); the comparison between Rio de Janeiro's streets, Paris's passages and Milan's galleries (85); the analogy between Bororo huts, Kuki dwellings, and Western women's hats (215); the association between the variety of Nambikwara honeys and the wide range of tastes of Burgundy wines (271); etc. And the actual relevance of these analogies is not what is really at stake here. As The Savage Mind later put it about the way the "logic of the concrete" works: "The real question is not whether the touch of a woodpecker's beak does in fact cure toothache. It is rather whether there is a point of view from which a woodpecker's beak and a man's tooth can be seen as 'going together"” (Lévi-Strauss 1966:9).

Tristes tropiques is not a warm, literary narrative compensating for the dryness and coldness of La Vie sociale et familiale des Indiens nambikwara; nor is it, as Clifford Geertz (1988) saw it, a melancholy, paradoxical tale of the conquest of anthropological knowledge. It is a huge variation on the analogies and differences between perceptual worlds. It is neither a triumphant nor a bitter account of fieldwork, but a gigantic patchwork — not a Conradian travelogue to "the extreme limits of the savage" but a Proustian reordering of the past.

In other words, Tristes tropiques's role is at least twofold: it is first a sort of inner experience of the logic of secondary qualities that provide the core of Lévi-Strauss's later work; it is also a formal experiment laying the foundation for the structural analysis of myths and classificatory systems. It is in Tristes tropiques that Lévi-Strauss for the first time does what he will continue to do in The Savage Mind and Mythologiques: search for correspondences, analogies, and differences between various ensembles whose intelligibility and organizing principles are not extracted by the anthropologist's rationality, but revealed through variations and comparisons. The only difference is that in Tristes tropiques, Lévi-Strauss is not going back and forth between classificatory systems or variants of a myth, but between various layers of his own past. In a way, then, Tristes tropiques is less a second book than a first one, making possible the anthropological work to comeless a supplement to the scholarly work than a condition of it. "Literature" here has nothing to do with representation anymore; it is just the site for experiences made with writing and through writing - in that sense, a true continuation of fieldwork. 
Thirty years after the founding of the Institut d'ethnologie and 17 years after the opening of the Musée de l'homme, French anthropology witnessed the beginning of a new era. The fetishization of "documents" and the insistence on collection of artifacts would gradually vanish (the Musée de l'homme would never recover its former prestige), but not the programmatic commitment to a science of mental facts. Nor did the relationships between French anthropology and literature come to an end; they would soon be reconfigured around structuralism. But the issue of cultural representation, an inheritance of museum positivism, was from then on relegated to the background.

"Why did British anthropologists write so much on rules of succession, economics, and land tenure, but neglected the relationship between modern arts, such as surrealism, and African art? Or put another way, why did French anthropologists write so much on art and mythology but ignored more down to earth subjects? Why did they make films when British anthropologists were doing kinship charts?... Why did British specialists of African anthropology write plainly, in an analytic manner, and the French lyrically, in an expressive manner?" (Douglas 1995:199-200). These questions, asked by Mary Douglas in 1992, voice a widely shared opinion among English-speaking anthropologists. However, rather than invoke "national personalities" that would account for the famous contrast between British pragmatism and the more speculative and philosophical temperament of the French, it might be more productive to study actual ethnographic writing practices and their variations, both within each anthropological tradition and between national traditions. The picture I have sketched is indeed very local, and distinctively French, especially with regard to the anthropologists' shared investment in an emphatic notion of literature coupled with a distrust of rhetoric and of hermeneutics. It is also specifically French in the commitment of anthropology to the Durkheimian project of a science of mental and affective states (a conception to which Bourdieu and even Lévi-Strauss are indebted despite the latter's indisputable break with Durkheimian orthodoxy: see Lévi-Strauss [1976]). The story would probably have been very different if the original paradigm of French anthropology had been less holistic or more interpretive: if, for instance, the French ethnographers had been assigned the task of accessing the "native's point of view," a phrase and a notion that are strikingly absent from the French anthropological tradition.

This specificity also accounts for some curious exchanges and cross-currents. Looking back at the studies from the 1980 s and 1990 s on the poetics of 
anthropology, one is struck by the strong presence of French authors like Ricoeur, Foucault, Barthes, and Bataille, which provided both theoretical frameworks and examples of experimental and anti-realistic displays of results. But curiously enough, these studies only rarely cite canonical examples from French anthropology, such as Marcel Mauss's, Georges Balandier's, or Pierre Bourdieu's works. ${ }^{3}$ The only French text that sometimes appears in those analyses of ethnographic textual conventions is Tristes tropiques - a book that neither Lévi-Strauss himself nor any French anthropologist ever considered actual anthropological work. Such an absence is not accidental, however, since the French tradition provides very little to analyze in terms of cultural representation. In fact, I would argue that it is this very duality between the two books that has precluded the production of ethnographic accounts; the ethnographic "results" are confined to the descriptive monograph while the account of the fieldwork, when there is one, is reserved for the non-scholarly work. The concern for representation of alien societies was never central as such, the guiding requirement being not to portray, depict, or interpret other cultures, but rather to reflect on social practices and theoretically isolated "social facts."

Conversely, the narrative that recounts the history of anthropology as a trajectory from objectifying representation to dialogism and co-production of knowledge is relevant for a more hermeneutic tradition: one where the productive dialogue, widening and deepening each interlocutor's perspective, realizes the ideal of a successful encounter between different systems of meanings. This narrative is consistent with an anthropological tradition which, from early on, believed that "the psychic organization of man" and "the mental processes of groups of men” were out of its scope (those were the concerns of "organic psychology and physiology"), and that the anthropologist's goal was the "understanding of civilization" and the "interpretation of man's mind" through "direct application to the [social facts] of the [ethnographer's] own psychic activities" (Kroeber 1915:284). But it might not account for the history of, say, 20th-century Japanese anthropology, whose destiny has been framed and shaped by totally different struggles and stakes and by a very peculiar relationship to literature, seen as both its lost origin and that uncanny Other which keeps haunting the project of (social) science (Ivy 1996). E. Valentine Daniel accounts for the "literary awakening in anthropology" in the 1980s by the fact that "philology is, after all, that nineteenth-century ancestor of both anthropology and literary study" (Daniel 1996:8, 11). That might very well be true in the United States, but not everywhere. Change the foundational operation-for example the way anthropology defined itself in contradistinction to literature or to folklore 
or to the natural sciences - and the subsequent relationships of anthropologists to literature (considered as both a corpus and a writing practice) and literary studies (considered as both a type of scholarship and an institutionalized discipline) will be greatly modified.

These historical and epistemological differences likely account at least in part for the "non-translation" of Writing Culture into French. This does not mean the infamous collection was not read by French anthropologists - it was, and it was also widely debated and discussed. But this controversial reception testifies to the difficulty of converting its theoretical stakes into a foreign frame of reference in which the notion of culture was never prevalent. ${ }^{4}$ Meanwhile, within the French tradition, the model of the two books has more or less imposed itself up until today, as is shown by such remarkable books as Georges Balandier's Ambiguous Africa (1966), Pierre Clastres's Chronicle of the Guayaki Indians (1998), or Philippe Descola's The Spears of Twilight (1996). This persistent pattern has to do with the prestige of literature in the French context, with an enduring distrust of rhetoric, with the recruitment and training of anthropologists in French universities, with publishing traditions, and with the imposing shadow of Tristes tropiques. But again, the divide between the two books should not be essentialized — not even as a divide between science and literature, since these notions are not stable or even comparable entities.

Finally, this national specificity might well account for the gap in scholarship mentioned earlier. It is indeed striking that, until recently (Parkin and de Sales 2010; Debaene 2010), no book, in France or in the United States, had ever been devoted to the academic and intellectual tradition that produced thinkers as influential as Marcel Mauss and Claude Lévi-Strauss. Many English-speaking anthropologists would account for this lack on the grounds that French anthropology is not quite a social science in the usual (i.e., Anglo-American) sense of the term. From Alfred Kroeber's and Robert Lowie's misgivings toward the Durkheimian group of “Année sociologique" in the 1930s (Kroeber 1935; Lowie 1937:196-221) to Clifford Geertz's denunciation of Lévi-Strauss's “cerebral savage” (Geertz 1967), French anthropology has often been described as overly theoretical, not factually grounded enough, and too literary in its expression. The 1967 controversy published in the journal Man about the translation of The Savage Mind is just one among many examples of the alleged "untranslatability" (starting with the very title of the book, La Pensée sauvage, which plays on the double meaning of the French pensée, which can mean both "pansy" and "thought") of a French anthropological mode of thought that would not satisfy the basic requirements of a scientific argument. 
However, rather than taking sides in these debates about the anthropological legitimacy of the French tradition, it might be useful to retain the lesson of the ethnographer by considering local categories and prevalent intellectual divides in context. The issue of the relationship between literature and anthropology cannot be abstracted from the local paradigms in which it was and continues to be framed. And this framing can be very different, depending on language, power relationships, space, and time. Given that anthropological traditions are local and that literary "fields" emerged on national bases, it is not surprising that the divide between disciplines or between discursive formations - as Foucault would have it — differs when considered from a French, a British, a German, a Japanese, or an American perspective. This shows that what needs to be compared is not only the disciplines or writing practices, but the different divides between disciplines and writing practices. This may be a lesson we can take from structural anthropology: what matters is not the differences, but the differences between the differences.

\begin{abstract}
This paper offers a study of French anthropological tradition in a comparative perspective. It focuses on French anthropologists' writing practices and, in particular, on a strikingly recurrent phenomenon: that French ethnographers, in addition to their scholarly work, often write a 'second book,' a literary account of their experience in the field. The study of the divide between these two books allows for a comparison with other national anthropological traditions, particularly the American one. It sheds light on some difficulties in cultural and intellectual translation between national traditions in social sciences. [French anthropology, ethnographic writing, anthropology and literature, national traditions in social sciences, Métraux, Lévi-Strauss, Mauss, Griaule, Tristes tropiques]
\end{abstract}

\title{
NOTES
}

1. By first generation, I mean the generation trained by Marcel Mauss in the 1920s and 1930s at the Institut d'ethnologie de Paris (created in 1925) and at the Musée d'ethnographie du Trocadéro, later Musée de l'homme (this last inaugurated in 1938). In striking contrast to the generation of their professors (Mauss, Lévy-Bruhl, Rivet), those students were the first generation of professional anthropologists for whom fieldwork was a requirement.

2. In most cases, the "literary" book was published after its scholarly counterpart, the only blatant exception being that of Leiris, whose diary was published right after his mission, while the two scholarly books drawn from his fieldwork appeared in 1948 and 1958. In Métraux's and Soustelle's cases, the two books were written more or less simultaneously.

3. James Clifford's studies of Maurice Leenhardt and Marcel Griaule are remarkable exceptions (Leenhardt and Griaule being themselves quite heterodox anthropologists in the French setting) (Clifford 1982, 1988). 
4. This difficulty is not only theoretical: it is also political, and reveals the difficulties some French anthropologists had in coming to terms with the colonial past of their discipline (see Piriou and Sibeud 1997; Sibeud 2002; Conklin 2002; de l'Estoile 2003).

\section{REFERENCES CITED}

Balandier, Georges

1966 [1957] Ambiguous Africa: Cultures in Collision. Helen Weaver, trans. New York: Pantheon.

Bataille, Georges

1956 “Un Livre humain, un grand livre.” Critique 105:100-112.

Bohannan, Laura (Elenore Smith Bowen [pseud.])

1954 Return to Laughter. New York: Harper.

Bourdieu, Pierre, ed.

1993 La Misère du monde. Paris: Ed. du Seuil.

Breton, André

1972 [1924] "Manifesto of Surrealism." In Manifestoes of Surrealism. Richard Seaver and Helen R. Lane, trans. Ann Arbor: University of Michigan Press.

Bruner, Edward M.

1993 Introduction to Anthropology and Literature. Paul Benson, ed. Pp. 1-26. Urbana: University of Illinois Press.

Clastres, Pierre

1998 [1972] Chronicle of the Guayaki Indians. Paul Auster, trans. New York: Zone Books.

Clifford, James

1981 “On Ethnographic Surrealism." Comparative Studies in Society and History 23(4):539-564.

1982 Person and Myth: Maurice Leenhardt in the Melanesian World. Berkeley: University of California Press.

1983a “On Ethnographic Authority.” Representations 2:118-146.

1983b "Power and Dialogue in Ethnography: Marcel Griaule's Initiation." In Observers Observed: Essays on Ethnographic Fieldwork. G. W. Stocking, ed. Pp. 121-156. Madison: University of Wisconsin Press.

1986 "Introduction: Partial Truths." In Writing Culture: The Poetics and Politics of Ethnography. James Clifford and George Marcus, eds. Pp. 1-26. Berkeley: University of California Press.

Conklin, Alice

2002 “The New 'Ethnology' and 'La Situation Coloniale' in Interwar France." French Politics, Culture and Society 20:29-46.

Debaene, Vincent

2008 “Notice of Tristes tropiques." In Euvres. Claude Lévi-Strauss. Pp. 1675-1774. Paris: Gallimard.

2010 L'Adieu au voyage. L'ethnologie française entre science et littérature, Paris: Gallimard.

Dianteill, Erwan

2012 "Anthropologie culturelle ou anthropologie sociale ? Une dispute transatlantique." L'Année sociologique 62(1):93-122.

Descola, Philippe

1996 The Spears of Twilight: Life and Death in the Amazon Jungle. Janet Lloyd, trans. New York: New Press.

De l'Estoile, Benoît

2003 "From the Colonial Exhibition to the Museum of Man: An Alternative Genealogy of French Anthropology." Social Anthropology 11(3):341-361. 
Douglas, Mary

1995 “Réflexions sur le Renard pâle et deux anthropologies." In L'Autre et le Sacré: Surréalisme, cinéma, ethnologie. C. W. Thompson, ed. Pp. 199-218. Paris: L'Harmattan.

Frazer, Sir James

1922 Preface to Argonauts of the Western Pacific: An Account of Native Enterprise and Adventure in the Archipelagoes of Melanesian New Guinea. Bronislaw MaliGeertz, Clifford nowski. London: Routledge.

1967 "The Cerebral Savage: The Structural Anthropology of Claude Lévi-Strauss." Encounter 28(4):25-32.

1988 "The World in a Text: How to Read Tristes tropiques." In Works and Lives: The Anthropologist as Author. Pp. 25-47. Stanford, CA: Stanford University Press.

Griaule, Marcel

1930 “Une mission ethnographique et linguistique en Éthiopie (1928-1929).” L'Afrique française, août 1930:453-454.

1933 Silhouettes et Graffiti abyssins. Paris: Larose.

1935 Jeux et divertissements abyssins. Paris: Ernest Leroux.

1957 Méthode de l'ethnographie. Paris: Presses Universitaires de France.

Handler, Richard

1991 [1934] Les Flambeurs d'hommes. Paris: Berg International.

1983 "The Dainty and the Hungry Man: Literature and Anthropology in the Work of Edward Sapir.” In Observers Observed: Essays on Ethnographic Fieldwork. George W. Stocking, Jr, ed. Pp. 208-231. Madison: University of Wisconsin Press.

1986 "Vigorous Male and Aspiring Female: Poetry, Personality, and Culture in Edward Sapir and Ruth Benedict." In Malinowski, Rivers, Benedict and Others: Essays on Culture and Personality. George W. Stocking, Jr, ed. Pp. 127-155. Madison: University of Wisconsin Press.

1990 "Ruth Benedict and the Modernist Sensibility." In Modernist Anthropology: From Fieldwork to Text. Marc Manganaro, ed. Pp. 163-180. Princeton, NJ: Princeton University Press.

Hegeman, Susan

1999 Patterns for America: Modernism and the Concept of Culture. Princeton, NJ: Princeton University Press.

Hollier, Denis

1992 “The Use-Value of the Impossible." October 60:3-24.

Ivy, Marilyn

1996 "Ghostlier Demarcations: Textual Fantasy and the Origins of Japanese Nativist Ethnology." In Culture/Contexture: Readings in Anthropology and Literary Study. E. Valentine Daniel and Jeffrey M. Peck, eds. Pp. 296-322. Berkeley: University of California Press.

Jamin, Jean

1986 "L'Ethnographie mode d'inemploi. De quelques rapports de l'ethnologie avec le malaise dans la civilisation." In Le Mal et la Douleur. J. Hainard and R. Kaehr, eds. Pp. 45-79. Neuchâtel: Musée d'ethnographie.

Kroeber, Alfred

1915 “Eighteen Professions.” American Anthropologist, n. s., 17(2):283-288.

1935 "History and Science in Anthropology." American Anthropologist, n. s., 37(4):539-569.

Lanson, Gustave

1964 [1902] “Contre la rhétorique et les mauvaises humanités.” In Essais de méthode, de critique et d'histoire littéraire. Pp. 57-60. Paris: Hachette. 
Leenhardt, Maurice

1932 Documents néo-calédoniens. Paris: Institut d'ethnologie.

1937 Gens de la Grande Terre. Paris: Gallimard

Leiris, Michel

1948 La Langue secrète des Dogons de Sanga. Paris: Institut d'ethnologie.

1958 La Possession et ses Aspects théâtraux chez les Ethiopiens de Gondar. Paris: Plon.

1996 [1934] "L’Afrique fantôme." In Miroir de l'Afrique. Pp. 86-887. Paris: Gallimard.

Lévi-Strauss, Claude

1948 La Vie familiale et sociale des Indiens nambikwara. Paris: Société des Américanistes.

1966 [1962] The Savage Mind. Chicago: University of Chicago Press.

1976 [1962] "What Ethnology Owes to Durkheim." In Structural Anthropology, Vol.

2. Pp. 44 48. Chicago: University of Chicago Press.

1991 [1988] Conversations with Claude Lévi-Strauss. Claude Lévi-Strauss and Didier Eribon. Paula Wissing, trans. Chicago: University of Chicago Press.

2012 [1955] Tristes tropiques. John Weightmann and Doreen Weightmann, trans. London: Penguin Books.

Lowie, Robert H.

1937 The History of Ethnological Theory. New York: Farrar \& Rinehart.

Manganaro, Marc

1990 Introduction to Modernist Anthropology: From Fieldwork to Text. Marc Manganaro, ed. Pp. 3-47. Princeton, NJ: Princeton University Press.

2002 Culture, 1922: The Emergence of a Concept. Princeton, NJ: Princeton University Press.

Mauss, Marcel

1933. Introduction to Silhouettes et Graffiti abyssins. M. Griaule. Pp. 5-7. Paris: Larose.

1990 [1925] The Gift: The Form and Reason for Exchange in Archaic Societies. W. D. Halls, trans. New York: Routledge.

2004 [1938] “Fait social et formation du caractère.” Sociologie et sociétés 36(2):135140.

2007 [1947] Manual of Ethnography. Dominique Lussier, trans. Oxford: Berghahn.

Métraux, Alfred

1940 Ethnology of Easter Island. Honolulu: Bishop Museum.

1941 L'Île de Pâques. Paris: Gallimard.

1988 [1925] “De la méthode dans les recherches ethnographiques.” Gradhiva 5:5671.

Parkin, Robert and Anne de Sales

2010 Out of the Study and into the Field: Ethnographic Theory and Practice in French Anthropology. New York: Berghahn.

Piriou, Anne and Emmanuelle Sibeud, ed.

1997 L'Africanisme en question. Paris: Éditions de l'Ecole des Hautes Études en sciences sociales, "Dossiers africains."

Poitry, Guy

1995-1996 “Carrefour des poètes: Michel Leiris et Alfred Métraux.” Bulletin du Centre Genevois d'Anthropologie 5.

Pratt, Mary Louise

1986 "Fieldwork in Common Places." In Writing Culture: The Poetics and Politics of Ethnography. James Clifford and George Marcus, eds. Pp. 27-50. Berkeley:

Rabinow, Paul University of California Press.

1977 Reflections on fieldwork in Morocco. Berkeley: University of California Press.

Rivet, Paul

1995 [1936] Preface to Mexique, terre indienne. J. Soustelle. Pp. 7-8. Paris: Hachette. 
Sapir, Edward

1917 "Realism in Prose Fiction." The Dial 63:503-506.

1922 “A Symposium of the Exotic." The Dial 73:568-571.

Sibeud, Emmanuelle

2002 Une science impériale pour l'Afrique? La construction des savoirs africanistes en France, 1878-1930. Paris: Éditions de l'École des Hautes Études en Sciences Sociales.

Soustelle, Jacques

1937 La Famille Otomi-Pame du Mexique central. Paris: Institut d'ethnologie.

1937b La Culture matérielle des Indiens Lacandons. Paris: Société des américanistes.

1995 [1936] Mexique, terre indienne. Paris: Hachette.

Tedlock, Barbara

1991 "From Participant Observation to the Observation of Participation: The Emergence of Narrative Ethnography.” Journal of Anthropological Research 41:69-94.

Valentine, Daniel E. and Jeffrey M. Peck

1996 "Culture/Contexture: An Introduction." In Culture/Contexture: Readings in Anthropology and Literary Study. E. Valentine Daniel and Jeffrey M. Peck, eds. Pp. 1-33. Berkeley: University of California Press. 